DOI: $\square$ https://doi.org/10.15407/techned2020.01.010

\title{
DC/DC CONVERTER WITH METERED ENERGY EXTRACTION AND TRANSMISSION
}

Journal
Publisher
ISSN
Issue
Pages

\section{Authors}

I.V. Volkov' ${ }^{1}$, S.V. Podolny ${ }^{2 \star *}$

1. Institute of Electrodynamics of the National Academy of Sciences of Ukraine,

pr. Peremohy, 56, Kyiv, 03057, Ukraine,

e-mail: ig.volkov@ukr.net

2. Sentinel Power Quality FZE, UAE

* ORCID ID : https://orcid.org/0000-0002-0696-0382

** ORCID ID : https://orcid.org/0000-0001-8111-0858

\begin{abstract}
Described is a new resonant voltage converter of buck/boost type with metered extraction of energy from the direct (rectified) current network and its metered transfer to the load. Electromagnetic processes in the input and output circuits of the converter are investigated taking into account the energy losses in its transistors, diodes and electromagnetic elements. Dependences between its parameters are found, at which its working capacity is ensured with minimal static and dynamic losses. The method of its calculation, aimed at achieving the maximum efficiency, is proposed. References 6 , figures 7 .
\end{abstract}

Key words: resonant converter, power transmitter, secondary power supply. 
Published: 16.01 .2020

\section{References}

1. Severns R.S., Blum G. Pulse DC voltage converters for secondary power supply. Moskva: Energoatomizdat, 1988. 296 p. (Rus)

2. Rashid M.H. Power Electronics. N.Y.: Academic Press, 2002. 895 p.

3. Asadi F., Eguichi K. Dynamics and Control of DC/DC Converters. N.Y.: M.C.Publishers, 2018. $230 \mathrm{p}$.

4. https://vdmais.ua/dc-dc-preobrazovatel-s-kpd-do-97/ (accessed 15.06.2019)

5. Volkov I.V., Podolny S.V. Controllable resonant type converter development for capacitor charging loads. Tekhnichna Elektrodynamika. 2017. No 6. Pp. 11-18. DOI: https://doi.org/10.1 5407/techned2017.06.011

6. Demirchian K., Neiman L. Teoretical basis of electrotechnic. Vol. 2. Sankt-Peterburg: Piter, 2006. 576 p. (Rus)

\section{PDF}

(ब)

This work is licensed under a Creative Commons Attribution-NonCommercial-NoDerivatives 4.0 International License 